\title{
THE TURKIC KINSHIP SYSTEM
}

\author{
Erhan TAŞBAŞ \\ Department of Turkish Language and Culture at National Chengchi University \\ No. 64, Sec. 2, Zhinan Rd., Wenshan District, Taipei, Taiwan \\ e-mail: ertasbas@gmail.com
}

Turkic kinship terminologies have been diversely classified as Turco-Mongolic, Siberian Generational, Omaha etc. by anthropologists as well as by linguists in previous studies. Obviously, it is difficult to claim an invariable kinship system covering all Turkic languages, since modern Turkic kin systems differentiated from not only the Proto-Turkic or Old Turkic system, but also within themselves over time. This paper presents an attempt to trace changes in the kinship systems from ProtoTurkic to the present as far as possible based on surviving well-attested kinship cognates.

Key words: Kinship terms, Turkic languages, family, terminology, vocabulary.

\section{Introduction}

It has been recognised that kinship terminology remains among one of the most archaic layers of vocabulary. Due to the fact that all languages have kinship terminology, this component of the vocabulary is considered as universal, but it varies from society to society.

The invention of kinship is virtually the invention of social life itself, and thus kinship terminology is specified by the characteristics of the society. In the Turkic case, patrilineal descent, the sedentary lineage system, lineage exogamy, and a form of patrilocal residence in which the conjugal nuclear family is a significant social unit, are all reflected in the kinship terminology of the Turkic peoples (Liljeström and Özdalga 2005: 103).

As a society changes, its culture and social structure also change. Especially, culture-language contacts (Russian, Arabic, Persian, Chinese, European), regional differences (Central Asia, Siberia, China, Minor Asia, Caucasia), nomadic/settled lifestyle, and ideologies (Islamist / communist / capitalist) make the Altaic (including 
Turkic) World socially and culturally heterogeneous (see for details Boikova and Rybakov 2006). In his essay on the kinship and social structure, Spencer (1960: 43) assesses that Turkish kinship system relates to Asiatic nomadism, the Muslim family, and the modern urban society.

Nevertheless, the structure of the family and society changes faster than the kinship system. This clarifies why Turkic peoples, such as Kyrgyz, Kazakh who retained nomadic-tribal lifestyle for centuries have almost completely preserved their kinship structure in spite of Soviet and post-Soviet modernisation. However, in languages that have lost their traditional kin classification, a word may remain unaltered, even though the concept has lost its former significance to the society. It is reflected very well in the Turkish proverb: Amca baba yarısidır 'Paternal uncle is half a father' which emphasises the equation $\mathrm{F}=\mathrm{FB}$ which is typical of the classificatory system, whereas modern Turkish kinship system distinguishes F and FB terminologically.

The steppe peoples were historically characterised by a type of Omaha kinship (Lindholm 1986: 342). In this system, the same term is used for father and father's brother and for mother and mother's sister. Parallel cousins are equated with siblings (Nanda and Warms, 2007: 252). But due to the internal and external factors, traditional structure has changed. To describe these changes of the kinship system and to suggest the reasons for kinship diversity among Turkic peoples, a detailed analysis based on five criteria of this system is in order.

\section{Basic Criteria of the Turkic Kinship System}

The fundamental factors of Turkic kin relations are based on being from the same place, belonging to the same lineage grouping and settling on the same street. All this provides social and economic solidarity for them.

A kinship system is usually based on descent and marriage, but the kinship relations may be described in terms of some criteria: (1) bifurcation, (2) collaterality, (3) generation, (4) age, (5) gender.

1. Bifurcation: Due to the fact that Turkic kinship is based on membership of patrilineal descent, the terms for the relatives on the father's side are more specific, whereas those on the mother's side are more classificatory, e.g. Kyr. eje 'paternal aunt, elder sister', ake 'paternal uncle, elder brother', ene 'paternal grandmother'. Relatives from mother's side are usually not called by distinct terms, but are indicated by the determiner tay preceeding these terms, e.g. Kyr. tay-eje 'maternal aunt', tay-ake 'maternal uncle', tay-ene 'maternal grandmother'. This difference originates in the inequal quality of the two relative lines. Thus, this system of kinship organisation in all Eurasian peoples (Bacon 1958: 192) is patrilineal and seems to be in accordance with the Omaha kinship structure where men who are members of the ego's mother's patrilineage are referred to with the term for mother's brother, regardless of age or generation (Nanda and Warms 2007: 253). 
Similarly, the fact that in the ego's generation, brothers and paternal male cousins are usually lumped together, but distinguished from maternal male cousins, reflects the patrilineal character of Turkic societies. Moreover, some languages, such as Kazakh, Kyrgyz have two different words for each paternal cousin according to the sex of the linking relative. Likewise, there are two words for a maternal cousin according to sex, e.g. Kaz. nemere ini 'paternal cousin (through uncle)', žiyen ini 'paternal cousin (through aunt)', nagaši ini 'maternal cousin (through uncle)', böle 'maternal cousin (through aunt)'; Kyr. tay 'maternal cousin (through uncle)', bölö 'maternal cousin (through aunt)'.

2. Collaterality: The basic social unit among the Turkic peoples, as among the other Altaic peoples, was the joint family. This family system was originally organised around the FF, and thus it did not distinguish between $\mathrm{oB}$ and FyB, BS and SS, B and FBS, and so on, e.g. Chuv. pičče, Trkm. aga, Bash. agay, Kar. aka 'older brother, father's young brother'; Kyr. ini 'little brother, nephew (brother's son), cousin (paternal uncle's son)', Yak. siän 'nephew/niece (through sister), grandchild (through daughter)'.

Orkhon Turkic contains attestations to the equation $\mathrm{oB}=\mathrm{FB}$ (eči 'older brother, paternal uncle') and BS = SS (ati 'grandson, nephew') (Krader 1963: 261). These equations were probably lost in modern Turkic languages due to the contact with neighbouring languages and the changes in the traditional way of life, hence collateral special kin terms distinguishing between lineal and collateral kin such as FB, FZ, FBC, FZC, SC are loanwords or semantic loans from other languages, e.g. Gag. čiču (< Bulg.) 'paternal uncle', Az. bibi 'paternal aunt' (< Per.), Trk. kuzen $(<$ Fr.) 'cousin', Kum. zukari 'cousin (from paternal uncle) (< Ndagh.)' Uzb. näbirä 'grandchild' ( $<$ Per.).

Due to geographical isolation and other factors, some languages, especially of Kipchak and Siberian Turkic, still preserve the equations $\mathrm{oB}=\mathrm{FB}, \mathrm{B}=\mathrm{FBS}$ and $\mathrm{BS}$ = SS, e.g. Tuv. akïy 'older brother, younger brother of father', Kyr. ini 'younger brother, paternal cousin (younger than ego), Yak. siän 'nephew/niece (through sister), grandchild (through daughter)'. But the western and southern Turkic languages, i.e. those in closer contact with Indo-European and the North Caucasian languages, use loanwords or semantic loans meaning 'paternal uncle', 'cousin' and 'grandchild'. In these languages, the terms in question entirely replaced the polysemic terms merging lineal and collateral kins, e.g. Uzb. ämäki, Az. ämi 'paternal uncle', Kum. zukari, Kbal. eki karnašdan tuygan 'cousin', Trk. torun and Uyg. nävrä 'grandchild'.

Apart from loanwords, some languages distinguish collateral from lineal relatives by descriptive compounds such as 'father's brother', 'father's brother's daughter', 'son's son', as well, e.g. Kum. atasïnï agasi 'father's older brother', Tuv. oglunun oglu 'grandson', Kkal. atalas kïz 'female cousin (through paternal uncle)', Chuv. xurïntaš pičče 'older male cousin (through paternal uncle)'.

3. Generation: Grønbech (1953: 127-128) describes the Turkish generations not as horizontal and absolute, but as vertical and relative. The family is regarded here not as 
successive layers of generations, but as a continuous string of individuals chronologically arranged, the sole factor determining the position of an individual being his date of birth. In accordance with this system, there is a merging of generations on the mother's side. All men of mother's side are called tagay 'mother's brother' regardless of their ages. But generational distinction is important on the father's side, because all members of father's side, such as 'grandfather', 'father', 'uncle' and 'old brother' may have authority over the family. That is why modern Turkic languages form 'age generations' such as $\mathrm{FF}=\mathrm{F}, \mathrm{FF}=\mathrm{FB}$ and $\mathrm{oB}=\mathrm{FB}$, and so forth. The 'father' is not only a kin term, it is also a symbol of the authority of the household. Therefore, in a traditional Turkic extended family where the eldest male is the head of the family, ego may refer to $\mathrm{FF}$ or $\mathrm{FoB}$ as $\mathrm{F}$ regardless of father being alive or dead, e.g. Trkm. ata, Sal. papa 'FF, F'; Bash. babay 'FF, FB, MB'; Uzb. (dial.) aga ' $\mathrm{F}, \mathrm{FB}, \mathrm{oB}$ '. In the case of descending generations, $\mathrm{BC}$ may be merged with $\mathrm{SC}$, e.g. Orkh. ati 'grandson, nephew', Yak. siän 'grandchild, nephew/niece (through female side)'.

The ego's generation, i.e. siblings and cousins, may be merged, both the ascending and the descending generations. While the older members of the ego's generation, i.e. $\mathrm{oB}$, are merged with the younger members of the ascending generations (usually with $\mathrm{FyB}$ ), the younger ones, i.e. $\mathrm{yB}$, are merged with all members of descending generations (usually with BS). This is especially true of Central Asian and Siberian Turkic, where traditional family system is more preserved, e.g. Chuv. pičce ' $\mathrm{FyB}, \mathrm{oB}$ ', Tuv. akïy ' $\mathrm{FB}, \mathrm{oB}$ ', Kyr. ini 'male relatives younger than ego'. It is also true of the case of Turkic terms for ogul (or bala) 'boy' and kyz 'daughter'. These terms occur in all modern Turkic languages and also mean 'boy' and 'girl', e.g. Tat. $u l$ ' $\mathrm{S}$ ', kiz ' $\mathrm{D}$ '. It suggests that boys and girls in Turkic societies are equated with $\mathrm{S}$ or $\mathrm{D}$, regardless of their generation. The term for $\mathrm{S}$ and $\mathrm{D}$ is extended to $\mathrm{SS}$ and SD, too, e.g. Yak. uol, Tat. ul 'S, SS'; Yak. kï̈s, Tat. kïz 'D, SD'.

Especially, languages which are considered by Turkologists to be relatively relevant for reconstruction purposes, such as Old Turkic, Chuvash, Yakut, and Middle Mongolian (Dziebel 2007: 238) have led to postulate that PT kinship system had an Omaha-type generational skewing, and therefore it equated relatives belonging to different generational levels, such as FBS $=\mathrm{BS}$ or FZD $=$ ZD. Such generational skewing was probably lost in some languages. It is especially true in the case of Western Turkic languages. These languages usually distinguish between two ascending and two descending generations, e.g. Trk. torun 'grandchild', ağabey 'elder brother', baba 'father', dede 'grandfather'.

4. Age: The criterion of relative age reflects the biological fact that relatives of the same generation are rarely identical in age. Of any pair, one must almost inevitably be older than the other (Murdock 1965: 105). In accordance with this generalisation, all Turkic languages have younger-older distinction on the basis of age between relatives of the same generation. Therefore, relatives are classified solely on the basis of the relative's age to ego regardless of generational differences. This terminological distinction is not only true of $\mathrm{B}$ and $\mathrm{Z}$, but also $\mathrm{FyB}$ and $\mathrm{FoB}$, and correspondingly 
between FyZ and FoZ. E.g. Chuv. pičče 'younger brother of father, older brother', muč $i$ 'older brother of father', akka 'younger sister of father, older sister', appa 'older sister of father'; Yak. ubay 'younger brother of father', abaga 'older brother of father'; Kaz. apa 'older sister', sigli 'younger sister'. The fact that it is preserved in Old Turkic and Medieval Mongolian sources (Bacon 1958: 61) suggests that Proto-Turkic had relative age distinction. In this sense Clauson (2005: 152) mentioned that while most peoples think in terms of generations, one's own, one's father's, one's children's and so on, the early Turks thought more in terms of age groups, and so, for example, used the same word for one's oB and one's FyB, e.g. Otk. ini 'young brother', ec $i$ 'older brother, paternal uncle'; sinil 'little sister', eke 'older sister, paternal aunt'.

In addition to these relationships, the Turkic peoples distinguish the relative age of two older siblings by compound terms formed of the words meaning 'big' and 'little', e.g. Kyr. kičinekey eje (little + older sister) 'the younger of my two older sisters', uluu eje (big, great + older sister) 'the older of two older sisters'; Trk. küçük ăgabey 'the younger of two older brothers', büyük ağabey 'the older of two older brothers'.

Due to the fact that traditional Turkic extended family is formed around the eldest male, the meanings of the terms expressing FF, F and FB are unstable. In traditional Turkic societies, especially in case of absence of the F or FF (death, etc.), FoB inherits the status of them as the head of the family due to his age, e.g. Trkm. ata, Sal. papa 'grandfather, father', Uyg. čoy ata (< č 'big' + ata 'father'), Sho. ulda (< ulug ada < ulug 'big, great' + ada 'father') 'grandfather, older brother of father'.

In Turkic languages, kin differences for relative age are usually neutralised in the ascending and descending generations. In other words, as the generational distance increases, the opposition between older and younger kin becomes less salient. Thus, the neutral terms for 'grandchild', 'grandfather' are obliterated in the single terms, such as torun, dede etc.

5. Gender: All Turkic languages have gender distinction for the ego's generation and ascending generations, but the first and second descending generations do not differentiate by gender, such as grandson/granddaughter and nephew/niece. This is strongly compatible with Greenberg's hypothesis (1990: 318-319) on the universal features of kinship terminologies, which claims that the closer a generation is to ego, the more unmarked it is and each ascending generation is, and the marked category never has more internal differentiation than the unmarked.

This is not always stable and therefore ignored, depending on certain special relationships. Thus, kinship terms differentiate not only according to the sex of relative, but also according to the sex of the speaker or linking relatives. It is characteristic especially of sibling terms. In some Central Asian Turkic languages, such as Kyrgyz, Kazakh, Uzbek, Bashkir etc., there are two distinct terms for a younger sister, depending on the sex of the speaker. While the term karïndaš and its variants are used only by men, women address their yZ or siyli and its variants, e.g. Kyr. karïndaš 'little sister (of a man)', sigli 'little sister (of a woman)', but oZ is referred to by a single term, e.g. Kaz. äpke, Kyr. eje. 
In the first and second descending generations, the nephews/nieces and grandchildren are distinguished according to the sex of the ego's siblings and children. While in the first descending generation, gender distinction is ignored for sister's children, not for brother's children, in the second descending generation, terms for both son's and daughter's children are neutralised terminologically, e.g. Trkm. ini for BS, karïndaš for $\mathrm{BD}$ and yegen for ZC; Kyr. jeen for ZC, DC and nebere for CC. This is explained by the fact that in Turkic kinship terminology $\mathrm{BC}$ is usually considered to be 'younger sibling', but ZC is only 'nephew/niece'.

The fact that most of the ancient and contemporary Central Asian languages, including also other Altaic languages (Bacon 1958, Pokrovskaja 1961), have single words for siblings' and childrens' children, implies that Proto-Turkic tended to classify the first and second descending generations in accordance with whether they are through male or female lines.

When a simple kin term is insufficient to specify a relationship, a compound kin term is used for this purpose. In such cases, a modifier, such as ogul 'son', kiz 'daughter' or bala 'child' etc. can be used if necessary to specify the sex of the relatives of descending generations, but this is not usual, e.g. Tat. běrtugannï kïzi 'niece', Sho. palazïnïy palazï 'grandchild (child's child)', Chuv. ečin eči 'grandchild (child's child)'.

\section{The Historical Development of Turkic Kinship Terminology}

The traditional Turkic kinship system originally belongs to Asiatic nomadism. Over time, this system has changed in various ways in different parts of the Turkic linguistic area. This is related to the fact that Turkic languages have a vast area of distribution and different historical backgrounds. Internal developments and outside influences determine the characteristics of the changes in kinship terminology. Since the fact that the Turkic peoples for more than 2000 years remained predominantly or partially pastoral nomadic (Baştuğ 1999), and nomadic pastoral life requires a relatively small and mobile group (Krader 1963: 281). Therefore, there is a considerable reason to suggest that the Proto-Turkic kinship system was reflecting a 'tribal genealogical' kin type. In tribal genealogical organisation a family may grow into a lineage group, and the latter into a tribal subsection composed of several lineages, without any radical change in the nature or functions of the group (Bacon 1958: 43). Traces of this structure persisted among many Central Asian Turkic peoples. However, the process of the transition from the clan/tribe to the nation accompanies the shift from nomadic to urban culture. This change has left traces not only in the kinship system, but also in social, political, economic and religious institutions. This issue was considered in detail by Gore (1990) and Friedrich (1966) in their books.

Even if the Proto-Turkic kinship terminology is difficult to know about, we can reconstruct the Old Turkic kinship system, because it is attested in writing. Most likely not all kin terms used in the 8th century are shown in the Orkhon inscriptions, but all recorded words imply that the Old Turkic kinship system is an example of the 
Omaha System (Baştuğ 1993). Omaha descent groups are characteristically patrilineal. In this system, relatives are classified according to their descent and their gender. Due to the fact that the Turkic family system has a patriarchal character, tracing a descent through the father's side of the family, paternal descent is decisive. Thus, there are more terms for father's side in comparison to mother's side.

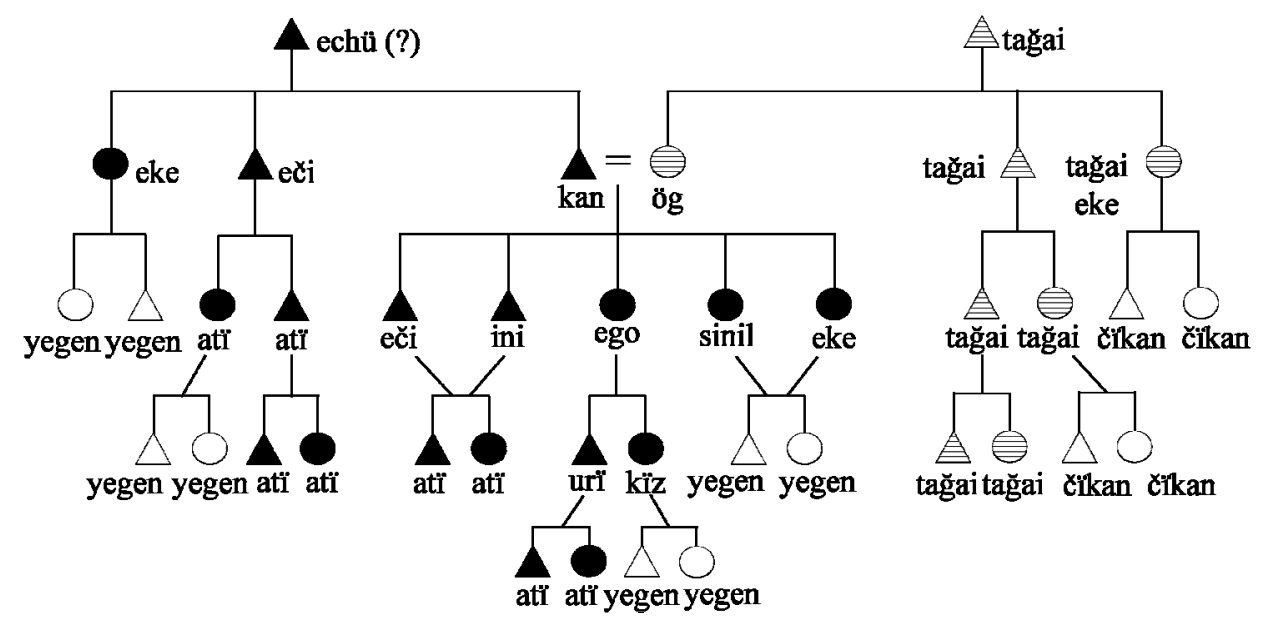

Figure 1. An Omaha model of Köktürk kin terms (Baştuğ 1993: 6)

During the early Seljuk years, however, the tribally organised Turkmen nomads began to settle, becoming in many cases semi-nomads who were still involved in sheep herding, and also engaged in agricultural production (Liljeström and Özdalga 2005: 104). It is also true of Turkic tribes in Central Asia. In many ways, the diversity in the use of kinship terminology in Turkic languages reflects changes from tribal to settled lifestyle. This verifies the fact that kinship terms in sedentary Turkic people are slightly more restricted in comparison to nomadic Turkic people. For instance, Turkic nomadic, semi-nomadic or semi-sedentary people are obligated to know the names of their at least seven direct blood ancestors (e.g. Kaz. žeti ata, Kyr. jeti ata), while sedentary people tend to forget this tradition. The principle of seven ancestors defines marriage rules, sex regulation, and incest taboo. Central Asian Turkic people believe that genes are transmitted through seven generations and marriage is prohibited between people of the same genetic pool.

Even if the Köktürk kinship system was substantially preserved in some scripts in the following periods (Old Uyghur, Khwarezmian, Chaghatay etc.), it is possible to determine that the terminological merging of lineal and collateral relatives has disappeared, and FB and FZ are referred to by distinct terms. These terms were consistently adopted from other languages, and have not been common to all Turkic area in the subsequent periods, but are used in restricted regions. These words are shown on the next page. 


\begin{tabular}{lllll}
\hline Word & from & Meaning & $\begin{array}{l}\text { Ancient } \\
\text { Languages }\end{array}$ & Modern Languages \\
\hline $\begin{array}{l}\text { 'amm } \sim \\
\text { 'ammi }\end{array}$ & Ar. & $\begin{array}{l}\text { paternal } \\
\text { uncle }\end{array}$ & $\begin{array}{l}\text { Krkh., Khwr., } \\
\text { Kipc., Chag. }\end{array}$ & $\begin{array}{l}\text { Trk. (dial.), Az., Uzb., } \\
\text { Khal. }\end{array}$ \\
\hline abaga & Mng. & $\begin{array}{l}\text { paternal } \\
\text { uncle }\end{array}$ & Kipc., Chag. & $\begin{array}{l}\text { Suyg., Tuv., Kumd., } \\
\text { Khak. }\end{array}$ \\
\hline bibi & Per. & $\begin{array}{l}\text { maternal } \\
\text { aunt }\end{array}$ & Kipc., Chag. & $\begin{array}{l}\text { Trk. (dial.), Az., Trkm., Uzb., Kumd. (dial.), } \\
\text { Khal. }\end{array}$ \\
\hline 'amma & Ar. & $\begin{array}{l}\text { maternal } \\
\text { aunt }\end{array}$ & Chag. & $\begin{array}{l}\text { Az., Trkm., Uyg., Uzb., } \\
\text { Khal., Tr. (dial.) }\end{array}$ \\
\hline
\end{tabular}

The Köktürk kinship system merges the first and second descending generations, in other words, $\mathrm{BC}, \mathrm{ZC}$ and $\mathrm{CC}$ are referred to by a single word atilyegen. But modern Turkic languages usually distinguish between the first and second generations by a loanword meaning 'grandson', e.g. Trk. torun ( $<$ Arm. pnnf $t^{h}$ orn $)$, Kyr. nebere (< Per. نبيره nabi:ra), Tat. onïk (<? Rus. внук vnuk) 'grandchild'. This suggests that the distinction between $\mathrm{BC} / \mathrm{ZC}$ and $\mathrm{CC}$ is secondary and developed afterwards, under the influence of neighbour languages. This can be regarded as one of the more critical words concerning the reconstruction of the PT kinship system, since it has provided support for ascribing the PT kinship system to the system in a state of transition between a Hawaiian and an Omaha system.

As shown in the table above, the kinship vocabulary has been diversified with different words referring to the same concept, as the Turkic linguistic area expands. This change does not only occur at lexical level, but also at conceptual. In terms of the reflection of the societal change on the kinship system, Friedrich's (1966) study is remarkable. The author indicates that some significant events (World War I, World War II, Bolshevik Revolution, collectivisation, urbanisation) in Russian history led to the rise of the nuclear family and it is reflected in linguistic changes including loss of kinship terms (about sixty terms in 1861 reduced to thirty in 1950). In the Turkic case, because of the fact that the proportion of the nuclear family is not at high level, and the traditional model of Turkic extended family is already widespread, urbanisation has not entirely changed the Turkic kinship system. If it is considered that industrialisation of the economy is accompanied by urbanisation and a modification of the social system including the kinship system (Gore 1990: 77), it is understood why Turkish (urbanisation rate in Turkey was $73.4 \%$ in 2015) distinguishes cousin and sibling, $\mathrm{FB}$ and $\mathrm{oB}, \mathrm{FZ}$ and $\mathrm{oZ}$ or unites $\mathrm{ZC}$ and $\mathrm{BC}$, while Kyrgyz (urbanisation rate of Kyrgyzstan was $35.7 \%$ in 2015 ) does not.

A traditional Turkic extended family gives authority to the oldest person of the family. In such a family system, F and FB or B and FBS/FZS have the same status from the standpoint of FF. This can explain why most Turkic languages do not distin- 
guish F and FB or B and FBC, e.g. Yak. ini 'brother, cousin'; Kyr. (dial.) akä 'father, little brother of father'. The most important effect of urbanisation on kinship terminology is the fact that it reinforces nuclear family, and therefore led the transformation of authority and administration of the home economy from grandfather to father. Consequently, the family has begun to be formed around the father.

Semantic changes in kinship terminology can also be related to internal factors. Due to the fact that the Turkic kinship system is originally classificatory, the development of the semantic shift of most kinship terms proceeded from more general to more specific. Pokrovskaja (1961: 77) describes this change from a common, undifferentiated and broader meaning to a more particular and concrete meaning, e.g. ogul 'child' > 'son', er 'man' > 'husband' etc. In addition to this, the semantic shift proceeds from close kins to more distant ones, i.e. from consanguineal to affinal ( $\mathrm{F} \rightarrow$ wife's $\mathrm{F}$ ), from paternal line to maternal line ( $\mathrm{oZ} \rightarrow \mathrm{MZ}$ ), from lineal to collateral (B $\rightarrow$ FBS), from ego's generation to ascending or descending generations (yB $\rightarrow \mathrm{BS}$ ). And this model is correlated to Greenberg's (1990: 318) hypothesis that lineal is unmarked as against collateral, consanguineal is unmarked as against affinal, male is unmarked as against female in regard to sex of nodal persons, older is unmarked in relation to younger. In regard to generation, there is a more complex set of relationships. In general, the closer a generation is to ego, the more unmarked it is. Likewise, each ascending generation is unmarked in relation to the corresponding descending generation.

\section{The Influence of Neighbouring Languages}

Among Modern Turkic languages, the Old Turkic kinship system is largely preserved in the languages spoken in Central Asia and Siberia, but West Kipchak and West Oghuz languages have lost their traditional kin classification as a result of contact with other languages (Indo-European and Caucasian). In this manner, Turkish is a remarkable example that shows how the changes in social and cultural structure affect the kinship system. In spite of its strong historical ties to the Islamic Middle Eastern and Central Asian world, many aspects of Turkish kinship show far more similarity to kinship patterns in the Mediterranean countries (Liljeström and Özdalga 2005: 109). Such outside influences on the kinship system have occurred in different places, in different ways.

\subsection{The Classification of Borrowings}

Turkic kinship vocabulary represents a mixture of words of Turkic and foreign origin depending on the contact languages. These words may be classified according to the nature of the borrowing itself as (1) direct borrowings, (2) semantic loans, and (3) calques.

Those of the first type are a consequence of the fact that an existing concept in the language is displaced by a counterpart in a foreign language. This kind of adaptation 
is commonly based on the fact that the foreign language is a lingua franca, e.g. Uzb. (dial.) hämširä 'mother, sister' (< Per. hamši:ra); Trk. peder 'father' ( $<$ Per. pidar); Kyr. papa 'father' (< Rus. papa); Gag. dädu 'grandfather' (< Bulg. dyado); Az. validä 'mother' (< Ar. vālida); Suyg. yeye 'grandfather' $(<$ Chin. yéyé); Kar. tata 'father' $\left(<\right.$ Pol. tata), Trk. torun 'grandchild' $\left(<\right.$ Arm. $t^{h}$ orn $)$, etc. In some cases, direct borrowings have a somewhat different meaning in the target language than in the source language, e.g. Tat. onik 'grandchild' (< Rus. vnuk 'grandson'), Az. bibi 'paternal aunt' $(<$ Per. bi:bi: 'lady, wife'), Trk. hala, Ctat. ala 'paternal aunt' ( $<$ Ar. hāla 'maternal aunt').

The semantic loans are expressing the concepts which are not found in the traditional Turkic kinship system. A semantic loan is borrowed for a word already existing in the target language, as a consequence of cultural and social relations especially with Indo-European languages, but such examples are very rare. The Turkish word amca (< aba ečesi 'father's older brother') (Tekin 1960: 291) is one of them.

The calques are words of the source language that were translated into a target language. The purpose of borrowing such words is to express new concepts for the traditional Turkic kinship system with new native words, e.g. Bash. ike turan ayay 'older male cousin (from paternal uncle)', Tat. ikě tugan éně 'younger male cousin (from paternal uncle)', Kar. eki karïndas ulandarï 'cousins' (< Rus. dvojurodnyj brat). In some cases, a loanword combined with a native word may be employed in Turkic languages to refer to new concepts. Kum. zukari kardaš 'cousin' ( $<$ Darg. uzikar 'cousin'), Kaz. nemere aga 'older male cousin from paternal uncle $(<$ Per. nabi:ra 'grandchild'), Uzb. ämäkiwäččä 'older male cousin from paternal uncle (ämäki $<$ Ar. 'amma 'paternal uncle' + wäčča $<$ Per. bačča 'child'.

\subsection{The Contact Languages}

Due to the great mobility of the Turkic people, the Turkic linguistic area is widespread, and its vocabulary reflects this character with the presence of loanwords and semantic loans which have resulted from language contacts. For instance, whereas the number of loanwords of Mongolic origin in the West Siberian Tatar language is not very high (about 100), the Tuvan language has more than 2200 loanwords of Mongolic origin (Rassadin 1980). The same applies to borrowing kin terms.

Loanwords have been borrowed in different ways from different languages and for different reasons. Mongolic, Chinese, Arabic, Persian and Russian are five major languages that have loaned more kin terms to Turkic languages than other contact languages.

Kinship terms of Mongolic origin must have been borrowed in different times of the history of Turkic languages.

Some of them can be found in almost all contemporary Turkic languages, e.g. Trk. (dial.) böle, Uzb. (dial.) bölä, Alt., Kyr. bölö, Kaz. böle 'cousin through maternal line' (< Mng. böle 'id.'); Az. guda, Uzb. kudä, Kyr., Sho., Kum. kuda, Tat. koda 'relative-in-law' ( $<$ Mng. kuda 'id.') etc. No loanwords except those from Mongolic languages could expand to all Turkic linguistic area. But this is not true of all loanwords from Mongolic. Some loanwords are geographically restricted to particular 
regions according to local and spesific contacts and cannot be expected to have an important influence on the whole Turkic kinship terminology. For example, the words ogo 'child, son', äjiy 'elder sister, aunt' which are restricted to Yakut and Dolgan languages, or the words *abaga 'paternal uncle, elder brother' (Yak. abaga, Alt. abaay, Kumd. abagay) and *öbögön 'ancestor, older male relative' (Alt. öbökö, Tuv. ögbe, Yak. öbügä, Khak. öbeke) are limited to some regions.

Loanwords of Chinese origin were loaned into Salar and Saryg Yughur (Yellow Uyghur) which are spoken in China and so strongly influenced by Chinese, e.g. Suyg. tata 'mother' (< Chin. tàitài 'wife'), Suyg. gunan 'paternal aunt' (< Chin. gūniang 'girl, young woman, paternal aunt'), Sal. sundzï 'grandson' (< Chin. sūnzi 'id.'); Sal. atsü 'maternal uncle' (< Chin. ājiù 'id.'), Sal. pō 'paternal uncle' (< Chin. bó 'id.'), Sal. ayi 'maternal aunt' (< Chin. àyi 'id.') etc.

Loanwords of Arabic origin are usually loaned into Oghuz and Karluk groups and some Kipchak languages which are under the influence of the Oghuz and Karluk languages. There are not any Arabic-Persian kinship loanwords in the languages outside the Islamic cultural sphere, e.g. Trk. hala, Ctat. ala 'paternal aunt', Az. hala, Uzb. (dial.) hålä 'maternal aunt' (< Ar. hāla 'maternal aunt'); Trk. valide, Az. validä, Uzb. (old) wålidä 'mother' (< Ar. vālida 'id.') etc.

In comparison to Arabic, loanwords of Persian origin are more widespread in the Turkic area. Loanwords from this language are used in Oghuz, Karluk and South Kipchak languages, e.g. Trkm. nebere 'relatives', Uyg. nävrä 'grandchild', Bash. nimärä 'child of grandchild', Kaz. nemere 'grandson' (< Per. nabi:ra 'grandchild'); Trk., Trkm. peder, Uzb. pädär 'father' (< Per. pidar 'id.'); Kyr. perzent, Uzb. färzänd, Uyg. pärzänd 'child' (< Per. farzand 'id.') etc.

Kinship terms of Russian origin are used in Turkic languages spoken in the enormous area of Tsarist Russia and the Soviet Union where Russian was the dominant language. Like in other languages, Russian loans mostly constitute recent layer, introduced at the end of the 19th century at the earliest and during the Soviet era at the latest (Hickey 2010: 662). The kinship terms of Russian origin are more common especially in the languages outside the Islamic cultural sphere, e.g. Yak. bïrāt 'brother' (< Rus. brat 'id.'), Yak., Dolg., Kyr., Kkal., Trkm. mama 'mother' (< Rus. mama 'id.'), Chuv. mïnuk 'grandchild' (< Rus. vnuk 'id.') etc.

In addition to the examples above, there are loanwords borrowed as a result of language contacts between two certain languages, e.g. Trk. kuzen 'cousin' ( $<$ Fr. cousin), Trk. torun (<Arm. pnn氏 $t^{h}$ orn $)$, Gag. čiču 'paternal uncle' (< Bulg. čičo 'id.'), Kum. zukari 'cousin through paternal uncle' (< Darg. uzikar 'cousin') etc. These terms may have been borrowed from a substrate or superstrate or adstrate language.

\section{Conclusion}

1. Turkic peoples of Eurasia are historically nomadic or semi-nomadic. Over time, this character had begun to be displaced by a sedentary lifestyle in some regions. Industrialisation and urbanisation had led to the fact that the nuclear family emerged 
in society, and kinship terminology kept up with this progress. Of course, nowadays some Turkic peoples still hold the nomadic or semi-sedentary lifestyle, and thus they are much closer to the traditional Turkic kinship system.

2. In terms of all criteria describing the character of the kinship system, the Turkic traditional kinship system shares strong similarities with other kinship systems of the Altaic languages in the Eurasian Steppe. In this sense, this system can be interpreted as a reflection of the Asiatic nomadic lifestyle. Old Turkic kinship terminology, which is an example of an Omaha kinship system as well as modern Turkic and Mongolic kinship systems, demonstrates that Proto-Turkic kinship structure is derivable from an anterior form which is similar to Omaha system in many respects.

3. The relatives of the maternal side are usually distinguished only by their gender, regardless of their age or generation. On the contrary, the relatives of the paternal side are classified by collaterality, generation, age and gender. Hence, there are a much more extensive number of terms for paternal relatives than for maternal relatives. In other words, relatives less remote from the ego have more terminological distinctions in relation to the more remote ones.

4. All layers of Turkic kinship terminology are open to external influences. Nevertheless, the loanwords, which do not correspond with the concepts in the traditional Turkic kinship system, seem to be less copyable than the concepts already existing in the target language. Thus, some languages may have the loanwords for native concepts rather than the loanwords for new concepts, but not vice versa.

\section{Abbreviations}

$\begin{array}{ll}\text { B } & \text { Brother } \\ \text { C } & \text { Child } \\ \text { D } & \text { Daughter } \\ \text { F } & \text { Father } \\ \text { M } & \text { Mother } \\ \text { oB } & \text { Older brother }\end{array}$

$\begin{array}{ll}\text { oZ } & \text { Older sister } \\ \text { S } & \text { Son } \\ \text { yB } & \text { Younger brother } \\ \text { yZ } & \text { Younger sister } \\ \mathrm{Z} & \text { Sister }\end{array}$

\section{Languages}

$\begin{array}{ll}\text { Alt. } & \text { Altay } \\ \text { Ar. } & \text { Arabic } \\ \text { Arm. } & \text { Armenian } \\ \text { Az. } & \text { Azerbaijanian } \\ \text { Bash. } & \text { Bashkir } \\ \text { Bulg. } & \text { Bulgarian } \\ \text { Bur. } & \text { Buryat } \\ \text { Chag. } & \text { Chaghatay } \\ \text { Chin. } & \text { Chinese } \\ \text { Chuv. } & \text { Chuvash }\end{array}$

Ctat. Crimean Tatar

Darg. Dargin

Fr. French

Gag. Gagauz

Kalm. Kalmyk

Kar. Karaim

Kaz. Kazakh

Kbal. Karachay-Balkar

Khak. Khakas

Khal. Khalaj 
Khwr. Khwarezmian

Kipc. Kipchak

Kkal. Karakalpak

Krkh. Karakhanid

Kum. Kumyk

Kumd. Kumandy

Kyr. Kyrgyz

Mng. Mongolian

Ndagh. Nakh-Daghestanian languages

Orkh. Orkhon Turkic

Otk. Old Turkic

Per. Persian

Pol. Polish
PT Proto-Turkic

Rus. Russian

Sal. Salar

Sho. Shor

Suyg. Saryg Uyghur

Tat. Tatar

Trk. Turkish

Trkm. Turkmen

Tuv. Tuvan

Uyg. Uyghur

Uzb. Uzbek

Yak. Yakut

\section{References}

BACON, Elizabeth E. 1958. A Study of Social Structure in Eurasia. New York: Wenner-Gren Foundation for Anthropological Research.

BAșTUĞ, Sharon 1993. 'Kök Türük Kinship Terminology: An Omaha Model.' Central Asiatic Journal 37/1-2: 1-19.

BAştuĞ, Sharon 1999. 'Tribe, Confederation and State among Altaic Nomads of the Asian Steppes.' In: Korkut A. ERTÜRK (ed.) Rethinking Central Asia: Non-Eurocentric Studies in History, Social Structure and Identity. London: Ithaca Press, 77-110.

Boikova, Elena V. and Rostislav B. RyBakov (eds.) 2006. Kinship in the Altaic World: Proceedings of the 48th Permanent International Altaistic Conference, Moscow 10-15 July, 2005. Wiesbaden: Harrassowitz Verlag.

Clauson, Gerard 2005. Studies in Turkic and Mongolic Linguistics. London and New York: RoutledgeCurzon.

DzIEBEL, German V. 2007. The Genius of Kinship: The Phenomenon of Human Kinship and the Global Diversity of Kinship Terminologies. Youngstown and New York: Cambria Press.

FrIEDRICH, Paul 1966. 'The Linguistic Reflex of Social Change: From Tsarist Russia to Soviet Russian.' Sociological Enquiry 36/2: 159-185.

Gore, Madhav S. 1990. Urbanization and Family Change. Bombay: Popular Prakashan.

GREENBERG, Joseph H. 1990. 'Universals of Kinship Terminology: Their Nature and the Problem of Their Explanation.' In: Keith DenNing and Suzanne Kemmer (eds.) On Language: Selected Writings of Joseph H. Greenberg. Stanford, CA: Stanford University Press, 310-327.

GrønBECH, Kaare 1953. 'The Turkish System of Kinship.' In: Studia Orientalia Ioanni Pedersen Septuagenario A.D. VII id. nov. anno MCMLIII a Collegis Discipulis Amicis Dicata. Hauniae: E. Munksgaard, 124-129.

HickeY, Raymond 2010. The Handbook of Language Contact. Malden: Wiley-Blackwell.

KRADER, Lawrence 1963. Social Organization of the Mongol-Turkic Pastoral Nomads. [Uralic and Altaic Series, Volume 20.] The Hague: Mouton.

LiLJeSTRÖM, Rita and Elisabeth ÖZDALGA (eds.) 2005. Autonomy and Dependence in the Family: Turkey and Sweden in Critical Perspective. Istanbul: Swedish Research Institute.

Lindholm, Charles 1986. 'Kinship Structure and Political Authority: The Middle East and Central Asia.' Comparative Studies in Society and History 28/2: 333-355.

Murdock, George P. 1965. Social Structure. New York: Macmillan Company. 
NANDA, Serena and Richard L. WARMS 2007. Cultural Anthropology. Belmont: Thomson Wadsworth.

PokrovskAJA, Ljudmila A. [Покровская, Людмила А.] 1961. 'Термины родства в тюркских языках.' In: Елизавета И. УБрятовА (ed.) Историческое развитие лексики тюркских языков. Москва: Наука, 11-81.

RASSADIN, Valentin I. [Рассадин, Валентин И.] 1980. Монголо-бурятские заимствования в сибирских тюркских языках. Москва: Наука.

SPENCER, Robert F. 1960. 'Aspects of Turkish Kinship and Social Structure.' Anthropological Quarterly 33/11: 40-50.

TeKIn, Talât 1960. "Amca ve Teyze Kelimeleri Hakkında [About the words "Amca" (uncle) and “Teyze” (aunt)].’ Türk Dili Araştırmaları Yıllı̆̆ -Belleten 1960: 283-294. 